doi: $10.2306 /$ scienceasia1513-1874.2014.40.204

\title{
Identification of phosphate-solubilizing bacteria from the bamboo rhizosphere
}

\author{
Samaporn Ruangsanka \\ Faculty of Science and Technology, Kanchanaburi Rajabhat University, Kanchanaburi 71190 Thailand \\ e-mail: samako@yahoo.com
}

Received 18 Mar 2013

Accepted 6 May 2014

\begin{abstract}
Some bacteria in the root zone of plants can solubilize phosphate making it available to the plant. Bacteria associated with bamboo roots may be a good source for development of bio-fertilizer for organic crop production. Here, 24 soil samples were collected from 8 species of bamboo, and 19 isolates of bacteria with the ability to solubilize phosphate were primarily selected based on the halo-to-colony ratio in Pikovskaya's medium. Five isolates with the highest ratios were cultured in vitro in a liquid medium containing mono-calcium phosphate $\left(\mathrm{Ca}\left(\mathrm{H}_{2} \mathrm{PO}_{4}\right)_{2}\right)$ and soluble phosphate was then determined. The five isolates were identified using the full $16 \mathrm{~S}$ rDNA sequencing method. Buttiauxella izardii had the highest soluble phosphate $(134 \mathrm{mg} / \mathrm{l})$ followed by Enterobacter cancerogenus $(110 \mathrm{mg} / \mathrm{l})$, Burkholderia ubonensis $(106 \mathrm{mg} / \mathrm{l})$, and E. hormaechei $(103 \mathrm{mg} / \mathrm{l})$, whereas Burkholderia pyrrocinia was lowest $(38 \mathrm{mg} / \mathrm{l})$. The isolates were further inoculated to soil planted with baby corn (Zea mays) in a pot experiment under an open environment. The experiment was not able to confirm the ability of these bacteria isolates to promote growth of the crop. The potential use of the isolates and the methods to improve the experiments for further studies are discussed.
\end{abstract}

KEYWORDS: Buttiauxella izardii, halo-to-colony ratio, Pikovskaya's medium, 16S rRNA sequencing, soluble phosphate

\section{INTRODUCTION}

Bacteria belonging to microbial community of the rhizosphere are known to form a symbiotic relationship with fine roots and enhance the plant capabilities to absorb nutrients ${ }^{1}$. Nitrogen-fixing bacteria and phosphate-solubilizing bacteria have been recognized as important microorganisms to agriculture ${ }^{2}$. It is thus interesting to explore phosphate solubilizing bacteria naturally abundant in the forests to solve phosphorus deficiency in agriculture.

Kanchanaburi is the most important area of baby corn production in Thailand. Production of baby corn in many areas in this province faces many problems that limit yield and product quality of the crop required by international market. Diseases, pests, and chemical contamination of the products cause serious problems for baby corn growers and exporters.

To address such problems and develop sustainable production of baby corn, the researchers are interested in using phosphate solubilizing bacteria to promote growth of the crop. The application of phosphate solubilizing bacteria is a promising means to combat phosphorus deficiency as the organisms can release phosphate to the soil in a form available for plants. Organisms effective in releasing available phosphate from low cost phosphate forms are likely to become promising candidates to develop bio-fertilizers that can replace high cost phosphate fertilizer and hence reducing the production costs. The use of bio-fertilizer that improve the fertilizer efficiency or replace chemical fertilizer is then worth exploring.

Several species of phosphate-solubilizing bacteria have been identified so far including Pseudomonas, Bacillus, Rhizobium, Bradyrhizobium, Berkholderia, having both wide and limited host ranges ${ }^{1}$. The bacteria are usually associated with rhizosphere, rhizoplane, or root tissues ${ }^{3}$. Phosphate-solubilizing microorganisms, particularly those belonging to the genera Bacillus sp. and Pseudomonas sp. and many others, release organic acids such as formic, acetic, propionic, lactic, glycolic, fumaric, and succinic acids to the soils ${ }^{4,5}$. Plants provide root exudates including amino acids, sugar or other compounds useful to the bacteria. Currently, attempts have been made to identify new phosphate-solubilizing bacteria with a better capacity from many sources to improve agricultural land and crop productivity.

Most phosphate-solubilizing bacteria are highly specific to a host plant ${ }^{6}$, and host-specificity in bacterial colonization is an important factor for success in biofertilization ${ }^{1}$. However, some phosphate solubilizing bacteria have a rather wide host range. Pseudomonas sp. dominated in the rhizosphere of maize ${ }^{7}$, 
soya bean ${ }^{8}$, oat, and wheat ${ }^{9}$, and Berkholderia sp. is being used as a biofertilizer in several important crops $^{10}$. Similarly, Azospirillum has several hosts such as maize, sorghum, and wheat ${ }^{1}$. As bamboo is a grass species related to cereal crops, the phosphatesolubilizing bacteria found in bamboo root zone may be useful for application to other cereal crops such as maize, sorghum, and rice. A single inoculant can be used for several crops, especially when using a nonspecific genus like Azospirillum ${ }^{11}$.

Un-disturbed soil in natural forest of a community in Kanchanaburi province was selected in this study because there would be a higher possibility to discover better phosphate-solubilizing bacteria than in agricultural soil. In a previous investigation in China, 56 bacteria species were found in root tissue, rhizoplane, and rhizosphere of moso bamboo ${ }^{3}$. Although the authors did not identify phosphate-solubilizing bacteria, there is still a possibility to discover this type of bacteria in bamboo root zone. In our earlier work, soil from the root zone of eight bamboo species was sampled, and a preliminary screening was carried out ${ }^{12}$.

The results of the previous work are more convincing, and the research is continuing to study phosphate assay in liquid culture and the effects of phosphate-solubilizing bacteria on growth parameters of the target host. The objectives of this study were to identify phosphate-solubilizing bacteria with effective capability of releasing soluble phosphorus and to test it on baby corn in a pot experiment. The results would be useful for further development of bio-fertilizer for sustainable production of organic baby corn and other target crops.

\section{MATERIALS AND METHODS}

\section{Soil samples in bamboo root zone}

Eight species of bamboo in the community's forest in Ban Pu Teuy village, Tha Sao subdistrict, Sai Yok district, Kanchanaburi province were selected in this study. The bamboo species included Cephalostachyum pergracile Munro, Bambusa bambos L. Voss, Gigantochloa albociliata (Munro) Kurz, G. densa (E.G. \& A. Camus), Thyrsostachys siamensis Gamble, Dendrocalamus membranaceus Munro, $D$. strictus Nees, and a long internode bamboo type with unknown species. Soil sampling followed the method recommended by the Department of agriculture. Briefly, the soil samples were collected at soil depth of $30 \mathrm{~cm}$ in the root zone of bamboo in June 2011. Twenty four soil samples were collected in the root zone of these bamboo species, and, on average, there were three samples for each bamboo species.
The samples were stored in sealable plastic bags under ambient conditions and sent immediately to laboratory for isolation of bacteria.

\section{Bacterial isolation, selection, and identification}

Bacterial isolation was carried out at the microbiology laboratory, Faculty of Science and Technology, Kanchanaburi Rajabhat University. Phosphate-solubilizing bacteria were isolated from 24 soil samples using selective media, Pikovskaya's medium (PVK). A total numbers of 196 bacterial isolates were originally obtained and were screened at the first stage of the study. After screening, 19 phosphate-solubilizing bacterial isolates were obtained, which were further screened based on the halo:colony ratio using the spot inoculation method. There were tree replications (spots) for each isolate, and five isolates were finally obtained for further evaluation.

The halo:colony ratio is the ratio of colony diameter and clear zone diameter of bacteria in culture medium. The clear zone can appear at the surface of the medium and the bottom of the medium. The bacteria with good ability to solubilize phosphate should have a high halo:colony ratio. This criterion is generally used for preliminary screening of phosphate-solubilizing micro-organisms including fungi and bacteria.

Further evaluation for phosphate-solubilizing ability of the five isolates was carried out in culture medium with three replications for each isolate, and soluble phosphate and $\mathrm{pH}$ were determined. The five phosphate-solubilizing bacteria were further identified by full $16 \mathrm{~S}$ rDNA sequencing method at the Biotechnology Centre in Pathumthani province.

\section{PCR amplification of $16 S$ rDNA}

DNA templates for PCR amplification were prepared by using a Genomic DNA mini kit (Blood/culture cell) (Geneaid Biotech Ltd., Taiwan). DNA coding for 16S rRNA regions was amplified by means of PCR with Taq polymerase ${ }^{13-15}$. A PCR product for sequencing $16 \mathrm{~S}$ rDNA regions was prepared by using the following two primers, 20F (5'-GAG TTT GAT CCT GGC TCA G-3' ${ }^{\prime}$, positions 9-27 on 16S rDNA by the $E$. coli numbering system) ${ }^{16}$ and $1500 \mathrm{R}$ (5'-GTT ACC TTG TTA CGA CTT-3', position 1509-1492 on $16 \mathrm{~S}$ rDNA by the $E$. coli numbering system) ${ }^{16}$. The PCR amplification was carried out with DNA Engine Dyad Thermal Cycler (Bio-Rad Laboratories).

One hundred $\mu \mathrm{l}$ of a reaction mixture contained 15-20 ng of template DNA, $2.0 \mu \mathrm{mol}$ each of the two primers, 2.5 units of Taq polymerase, $2.0 \mathrm{mM}$ $\mathrm{MgCl}_{2}, 0.2 \mathrm{mM} \mathrm{dNTP}$, and $10 \mu \mathrm{l}$ of $10 \times \mathrm{Taq}$ buffer, 
pH 8.8, containing $\left(\mathrm{NH}_{4}\right)_{2} \mathrm{SO}_{4}, 750 \mathrm{mM}$ Tris- $\mathrm{HCl}$, $200 \mathrm{mM}\left(\mathrm{NH}_{4}\right)_{2} \mathrm{SO}_{4}$, and $0.1 \%$ Tween 20. The PCR amplification was programmed to carry out an initial denaturation step at $94^{\circ} \mathrm{C}$ for $3 \mathrm{~min}, 25$ cycles of denaturation at $94^{\circ} \mathrm{C}$ for $1 \mathrm{~min}$, annealing at $50^{\circ} \mathrm{C}$ for $1 \mathrm{~min}$, and elongation at $72^{\circ} \mathrm{C}$ for $2 \mathrm{~min}$, followed by a final amplification step at $72^{\circ} \mathrm{C}$ for $3 \mathrm{~min}$. The PCR product was analysed by $0.8 \%(\mathrm{w} / \mathrm{v})$ agarose gel electrophoresis and purified with a QIAquick PCR purification kit (QIAGEN GmbH, Hilden, Germany). The purified PCR product was stored at $-20^{\circ} \mathrm{C}$ for further step.

\section{Direct sequencing of $16 \mathrm{~S}$ rDNA}

Direct sequencing of the single-banded and purified PCR products (ca. 1500 bases, on 16S rDNA by the $E$. coli numbering system) ${ }^{16}$ was carried out. Sequencing of the purified PCR products was carried out with an ABI PRISM BigDye Terminator Ready Reaction Cycle Sequencing Kit (version 3.1, Applied Biosystems, Foster City, California, USA). The primers 27F ( $5^{\prime}$-AGA GTT TGA TCM TGG CTC AG- $\left.3^{\prime}\right)$ and 800R ( $5^{\prime}$-TAC CAG GGT ATC TAA TCC- $3^{\prime}$ ) for partial sequencing, and additional 518F ( $5^{\prime}$-CCA GCA GCC GCG GTA ATA CG- $\left.3^{\prime}\right)$ and 1492R (5'-TAC GGY TAC CTT GTT ACG ACT T-3') for full length sequencing were used for sequencing of 16S rDNA.

The sequencing reaction mixture $(10 \mu \mathrm{l})$ contained 5-20 ng of template DNAs, $2.0 \mu \mathrm{l}$ of BigDye terminator ready reaction mixture, 5-20 ng of DNA template, $1.6 \mathrm{pmol}$ of sequencing primer, $1.5 \mu \mathrm{l}$ of $5 \times$ BigDye sequencing buffer and deionized water. The PCR reactions were carried out as follows: an initial denaturation step at $96^{\circ} \mathrm{C}$ for $30 \mathrm{~s}, 25$ cycles of denaturation at $96^{\circ} \mathrm{C}$ for $10 \mathrm{~s}$, annealing at $50^{\circ} \mathrm{C}$ for $5 \mathrm{~s}$, and elongation at $60^{\circ} \mathrm{C}$ for $4 \mathrm{~min}$. Then, the $\mathrm{PCR}$ products were precipitated in ethanol/acetate, washed with $70 \%$ ethanol, dried in a heat box at $90{ }^{\circ} \mathrm{C}$ for $1 \mathrm{~min}$, and stored at either $4^{\circ} \mathrm{C}$ or $-20^{\circ} \mathrm{C}$. The DNA pellets were resuspended in $20 \mu$ of a terminator sequencing reagent, mixed on a vortex and spun down. The double-stranded DNA was completely separated by heating at $95^{\circ} \mathrm{C}$ for $2 \mathrm{~min}$, and immediately placed on ice, until ready to load on instrument. The DNA sequencing was performed on an ABI Prism 3730XL DNA Sequence (Applied Biosystems, Foster City, California, USA).

\section{Sequence analysis}

The nucleotide sequences obtained from all primers were assembled using the contig assembly program, an accessory application in BIOEDIT (a biologi- cal sequence alignment editor program, see www. mbio.ncsu.edu/BioEdit/BioEdit.html). The identification of phylogenetic neighbours was initially carried out using BLAST $^{17}$ and MEGABLAST ${ }^{18}$ against the database of type strains with validly published prokaryotic names ${ }^{19}$. The 50 sequences with the highest scores were then selected for the calculation of pairwise sequence similarity using global alignment algorithm, which was implemented at the EzTaxon server (www.eztaxon.org) ${ }^{19}$.

\section{Effects of phosphate-solubilizing bacteria on growth of baby corn}

Five isolates of phosphate-solubilizing bacteria used in this study include Burkholderia pyrrocinia, Burkholderia ubonensis, Enterobacter cancerogenus, E. hormaechei and Buttiauxella izardii previously selected because of a high halo:colony ratio and phosphate-solubilizing ability. The isolates were inoculated into the soil used to plant baby corn (Zea mays) in pot experiment under open environment. The experiment was undertaken in Borploy district, Kanchanaburi province in July to August 2011. Soil was collected from baby corn field, analysed for chemical properties, and steam-sterilized prior to use. The sterilized soil was then loaded into plastic containers with $23 \mathrm{~cm}$ in diameter and $19 \mathrm{~cm}$ in height, containing $1 \mathrm{~kg}$ of soil for each container. There was one pot for each treatment in a replication and one container had one plant.

Twelve treatments consisting of sterilized soil control, phosphate $(\mathrm{P})$, B. pyrrocinia, B. ubonensis, E. cancerogenus, E. hormaechei, B. izardii, B. pyrrocinia $+\mathrm{P}$, B. ubonensis $+\mathrm{P}$, E. cancerogenus $+\mathrm{P}$, E. hormaechei $+\mathrm{P}$, and $B$. izardii $+\mathrm{P}$ were assigned in a completely randomized design with five replications making a total of 60 pots. Inoculation of the bacteria was accomplished by incorporating $1 \mathrm{ml}$ of cell suspension into each pot. For the pots containing phosphate, mono-calcium phosphate $\left(\mathrm{Ca}\left(\mathrm{H}_{2} \mathrm{PO}_{4}\right)_{2}\right)$ was incorporated into the soil at the rate of $10 \mathrm{~g}$ per pot. The floor was covered with plastic sheets to prevent microbial contamination of the pots. The seeds of baby corn hybrid SG 17 were over-planted and thinned to obtain one plant per pot. Water was applied to the experiment in the morning and the evening to avoid water stress.

The plants were allowed to grow for 30 days after planting (DAP). Plant height was recorded at 30 DAP from the soil surface to the highest leaf tip. Then the plants were harvested, and roots and shoots separated. The plant samples were oven-dried at $70^{\circ} \mathrm{C}$ for $48 \mathrm{~h}$ or until constant weight. Then root dry weight and shoot 
Table 1 Halo:colony ratio of 19 isolates of bacteria from root zone of different species of bamboo in Thailand.

\begin{tabular}{lcc}
\hline Bamboo species & $\begin{array}{c}\text { Phosphate-solu- } \\
\text { bilizing bacteria }\end{array}$ & $\begin{array}{c}\text { Halo:colony } \\
\text { ratio }\end{array}$ \\
\hline C. pergracile \#3 & B. ubonensis & $3.33^{\mathrm{c}}$ \\
D. membranaceus \#11 & $\begin{array}{c}\text { E. cancerogenus } \\
\text { E. hormaechei }\end{array}$ & $4.27^{\mathrm{b}}$ \\
D. membranaceus \#5 & B. pyrrocinia & $2.71^{\mathrm{b}}$ \\
G. albociliata \#3 & B. izardii & $7.11^{\mathrm{a}}$ \\
C. pergracile \#2 & NI & $2.00^{\mathrm{ef}}$ \\
D. strictus \#2 & NI & $2.15^{\mathrm{def}}$ \\
D. strictus \#3 & NI & $2.30^{\mathrm{de}}$ \\
D. strictus \#4 & NI & $1.60^{\mathrm{ef}}$ \\
T. siamensis \#1 & NI & $1.50^{\mathrm{fg}}$ \\
T. siamensis \#7 & NI & $1.80^{\mathrm{ef}}$ \\
D. strictus \#1 & NI & $1.53^{\mathrm{f}}$ \\
D. membranaceus \#2 & NI & $0.40^{\mathrm{h}}$ \\
B. bambos \#1 & NI & $0.60^{\mathrm{h}}$ \\
Long internode bamboo \#2 & NI & $0.60^{\mathrm{h}}$ \\
G. densa \#4 & NI & $0.75^{\mathrm{h}}$ \\
G. albociliata \#1 & NI & $0.80^{\mathrm{gh}}$ \\
D. membranaceus \#1 & NI & $0.50^{\mathrm{h}}$ \\
D. membranaceus \#8 & NI & $0.60^{\mathrm{h}}$ \\
D. membranaceus \#12 & & 1.89 \\
Mean & &
\end{tabular}

NI: Species could not be identified.

Means in the same column with the same letter(s) are not statistically different $(p>0.05)$ by DMRT.

dry weight were recorded.

\section{Data analysis}

Data for the halo:colony ratio, soluble phosphate, $\mathrm{pH}$, plant height, root dry weight, and shoot dry weight were subjected to ANOVA according to the experimental designs. Mean differences were determined at 0.05 probability level, and Duncan's multiple range test (DMRT) was used to compare means. Group comparison between isolates without $\mathrm{P}$ and isolates with $\mathrm{P}$ was also carried out by averaging the treatments in each group, and the groups were considered as single treatments. All calculations were done in MstAT- ${ }^{20}$. Correlation coefficients among the halo :colony ratio, soluble phosphate and $\mathrm{pH}$ were also computed to determine the relationships among these traits using MiCROSOFT EXCEL.

\section{RESULTS AND DISCUSSION}

\section{Selection of phosphate-solubilizing bacteria}

In this study, 19 isolates of bacteria that showed the highest halo:colony ratio were selected (Table 1). The halo:colony ratio indicated that these isolates were the putative bacteria with phosphate-solubilizing ability. The range of halo:colony ratios in this study was rather wide, ranging from 0.40 in $B$. bambos $\# 1$ to 7.11 in $C$. pergracile $\# 2$, and five isolates with the highest halo: colony ratio in descending order were C. pergracile \#2 (7.11), D. membranaceus \#5 (4.61),
Table 2 Halo:colony ratio, soluble phosphate and $\mathrm{pH}$ of five bacterial isolates from root zone of different bamboo species in Thailand.

\begin{tabular}{|c|c|c|c|c|}
\hline Source name & $\begin{array}{l}\text { Identified } \\
\text { name }\end{array}$ & $\begin{array}{l}\text { Halo: } \\
\text { colony } \\
\text { ratio }^{\dagger}\end{array}$ & $\begin{array}{c}\text { Soluble } \\
\text { phosphate } \\
(\mathrm{mg} / \mathrm{l})\end{array}$ & $\mathrm{pH}$ \\
\hline G. albociliata \#3 & B. pyrrocinia & $2.76^{\mathrm{cd}}$ & $38^{\mathrm{c}}$ & 5. \\
\hline C. pergracile \#3 & B. ubonensis & $3.33^{\mathrm{c}}$ & $106^{\mathrm{b}}$ & \\
\hline D. membranaceus \#11 & E. cancerogenus & $4.27^{\mathrm{b}}$ & $110^{\mathrm{b}}$ & \\
\hline D. membranaceus \#5 & E. hormaechei & $4.61^{\mathrm{b}}$ & $103^{\mathrm{b}}$ & \\
\hline C. pergracile \#2 & B. izardii & $7.11^{\mathrm{a}}$ & $134^{\mathrm{a}}$ & 3 \\
\hline
\end{tabular}

'Excerpted from Table 1 for comparison with soluble phosphate and $\mathrm{pH}$.

Means in the same column with the same letter(s) are not statistically different at 0.05 probability level by DMRT.

D. membranaceus \#11 (4.27), C. pergracile \#3 (3.33) and G. albociliata \#3 (2.76).

The halo:colony ratios for bacteria in this study were much higher than 1.17-2.96 for phosphate-solubilizing fungi in our previous findings in asparagus root zone ${ }^{21}$. The colonies of the bacteria were however much smaller than those of fungi because bacteria had much slower growth than fungi, and the growth character would affect their ability to solubilize phosphate.

C. pergracile \#2 had the highest soluble phosphate $(134 \mathrm{mg} / \mathrm{l})$, but it had the lowest $\mathrm{pH}$ (3.4) (Table 2). In contrast, G. albociliata \#3 had the lowest soluble phosphate $(38 \mathrm{mg} / \mathrm{l})$, but it had the highest $\mathrm{pH}$ (5.3). C. pergracile \#2 was also highest for halo:colony ratio, whereas G. albociliata \#3 was lowest. C. pergracile \#3, D. membranaceus \#5 and D. membranaceus \#11 were intermediate for soluble phosphate, $\mathrm{pH}$, and halo:colony ratio.

It is interesting to note here that soluble phosphate had a positive and highly significant correlation with halo:colony ratio (0.98), but these traits had negative and significant correlations with $\mathrm{pH}(-0.91$ for soluble phosphate and -0.89 for the halo:colony ratio) (data not shown). In other investigations, a close association was evident between phosphate-solubilizing ability and growth rate which is an indicator of active metabolism $^{22}$, and phosphate-solubilizing activity of bacterial strains was associated with the release of organic acids and a drop in the $\mathrm{pH}$ of the medium ${ }^{23}$. Reduction in the medium $\mathrm{pH}$ together with an increase in halo:colony ratio and soluble phosphate indicates that the bacteria secreted organic acids to solubilize phosphate ${ }^{24,25}$.

Five isolates with the highest soluble phosphate could not be identified in the culture medium because they were very similar (Fig. 1). The isolates were later identified for their species using full $16 \mathrm{~S}$ 

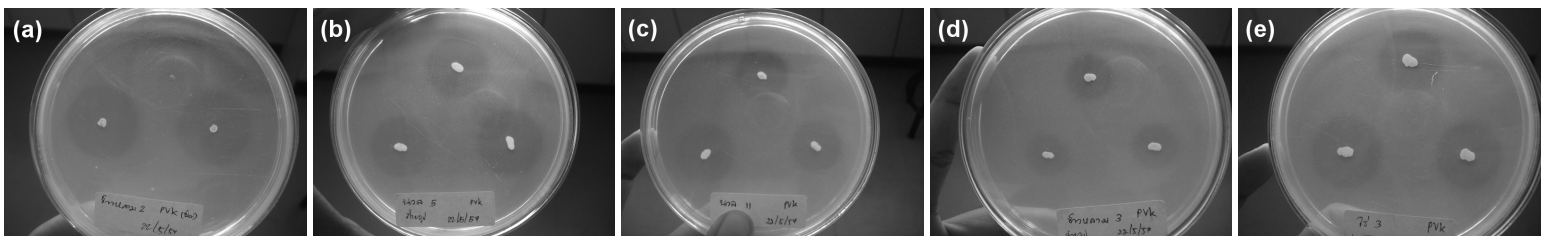

Fig. 1 Spot inoculation of five phosphate solubilizing bacterial isolates for determining the halo-to-colony ratio: (a) B. izardii, (b) E. hormaechei, (c) E. cancerogenus, (d) B. ubonensis, and (e) B. pyrrocinia.

Table 3 Identification of five phosphate solubilizing bacterial isolates using full $16 \mathrm{~S}$ rDNA sequencing method.

\begin{tabular}{lccc}
\hline Bamboo species & Bacterial species & $\begin{array}{c}\% \\
\text { similarity }\end{array}$ & $\begin{array}{c}\text { Accession } \\
\text { number }\end{array}$ \\
\hline D. membranaceus \#5 & E. hormaechei & $99.31 \%$ & AB898032 \\
D. membranaceus \#11 & E. cancerogenus & $99.14 \%$ & AB898033 \\
C. pergracile \#3 & B. ubonensis & $99.39 \%$ & AB898034 \\
G. albociliata \#3 & B. pyrrocinia & $99.64 \%$ & AB898035 \\
C. pergracile \#2 & B. izardii* & $98.61 \%$ & AB898036 \\
\hline * family Enterobacteriacae & &
\end{tabular}

* family Enterobacteriaceae

rDNA sequencing method. C. pergracile \#2 was classified as B. izardii (family Enterobacteriaceae) (Table 3). This species was the most promising for development of bio-fertilizer because of high soluble phosphate in vitro. G. albociliata \#3 was identified as $B$. pyrrocinia, $C$. pergracile \#3 was identified as B. ubonensis, D. membranaceus \#11 was identified as E. cancerogenus, and D. membranaceus \#5 was identified as $E$. hormaechei. These species, although produced lower soluble phosphate than did B. izardii, might perform well under field conditions.

The bacterial genera Burkholderia and Enterobacter identified in this study with capability of releasing soluble phosphate have been reported previously ${ }^{1}$. Buttiauxella izardii was also identified as potential microorganism for remediation of heavy metal-cadmium which will be applicable to decontaminate the environment ${ }^{26}$. These genera have been isolated from different plant hosts, indicating a wide host range. Enterobacteria have been isolates from citrus, cocoa, eucalyptus, soya bean, and sugarcane ${ }^{27}$, whereas Burkholderia are associated in roots of sug$\operatorname{arcane}^{28,29}$, rice ${ }^{30}$, and maize ${ }^{29}$. In bamboo, previous research found one species of Enterobacter and six species of Burkholderia from a total number of 56 species of bacteria from root tissue, rhizosphere, and rhizoplane ${ }^{3}$, and B. pyrrocinia is common to this study. The results indicated that Burkholderia are abundant in bamboo roots. The authors however did not find $B$. izardii in bamboo ${ }^{3}$. From the previous studies, there is a possibility that these isolates may be applied to baby corn as a target host. Some Burkholde-
Table 4 Plant height, shoot dry weight and root dry weight of baby corn received different treatments of phosphate and phosphate solubilizing bacteria in pot experiment.

\begin{tabular}{lcccc}
\hline Treatment & $\begin{array}{c}\text { Plant } \\
\text { height } \\
(\mathrm{cm})\end{array}$ & $\begin{array}{c}\text { Shoot } \\
\text { dry weight } \\
(\mathrm{g})\end{array}$ & $\begin{array}{c}\text { Root } \\
\text { dry weight } \\
(\mathrm{g})\end{array}$ & $\begin{array}{c}\text { Root: } \\
\text { shoot } \\
\text { ratio }\end{array}$ \\
\hline Phosphate $(\mathrm{P})$ alone & $25.8^{\mathrm{abc}}$ & $4.07^{\mathrm{bcd}}$ & $1.50^{\mathrm{ab}}$ & $0.38^{\mathrm{ab}}$ \\
E. cancerogenus & $20.7^{\mathrm{de}}$ & $3.33^{\mathrm{cd}}$ & $1.48^{\mathrm{ab}}$ & $0.47^{\mathrm{ab}}$ \\
E. hormaechei & $27.2^{\mathrm{ab}}$ & $5.95^{\mathrm{ab}}$ & $1.48^{\mathrm{ab}}$ & $0.31^{\mathrm{b}}$ \\
B. ubonensis & $19.2^{\mathrm{e}}$ & $2.97^{\mathrm{d}}$ & $1.68^{\mathrm{ab}}$ & $0.61^{\mathrm{a}}$ \\
B. pyrrocinia & $24.3^{\mathrm{bc}}$ & $4.78^{\mathrm{bcd}}$ & $1.41^{\mathrm{ab}}$ & $0.31^{\mathrm{b}}$ \\
B. izardii & $23.7^{\mathrm{cd}}$ & $4.26^{\mathrm{bcd}}$ & $1.16^{\mathrm{b}}$ & $0.31^{\mathrm{b}}$ \\
E. cancerogenus $+\mathrm{P}$ & $24.0^{\mathrm{bc}}$ & $3.79^{\mathrm{bcd}}$ & $1.69^{\mathrm{ab}}$ & $0.56^{\mathrm{ab}}$ \\
E. hormaechei $+\mathrm{P}$ & $28.0^{\mathrm{a}}$ & $7.27^{\mathrm{a}}$ & $2.40^{\mathrm{a}}$ & $0.44^{\mathrm{ab}}$ \\
B. ubonensis $+\mathrm{P}$ & $24.2^{\mathrm{bc}}$ & $4.34^{\mathrm{bcd}}$ & $2.04^{\mathrm{ab}}$ & $0.45^{\mathrm{ab}}$ \\
B. pyrrocinia $+\mathrm{P}$ & $26.7^{\mathrm{abc}}$ & $5.69^{\mathrm{ab}}$ & $1.99^{\mathrm{ab}}$ & $0.34^{\mathrm{ab}}$ \\
B. izardii $+\mathrm{P}$ & $26.5^{\mathrm{abc}}$ & $5.35^{\mathrm{abc}}$ & $1.87^{\mathrm{ab}}$ & $0.35^{\mathrm{ab}}$ \\
Blank control & $28.8^{\mathrm{a}}$ & $7.50^{\mathrm{a}}$ & $2.13^{\mathrm{ab}}$ & $0.28^{\mathrm{b}}$ \\
\hline
\end{tabular}

Means in the same column with the same letter(s) are not statistically different at 0.05 probability level by DMRT.

ria species are able to fix nitrogen ${ }^{31}$, increasing its utility in agriculture.

Although some species has not been reported to occur in baby corn, since they have a wide host range, they may be used in the production of organic baby corn. However, more investigations are still required, including inoculation methods for large scale production, extensive field experiments, and test of different forms of phosphate and species of phosphate-solubilizing bacteria. The use of Buttiauxella izardii to remedy heavy metal contamination in the soil is also promising.

\section{Effects of phosphate-solubilizing bacteria on growth of baby corn}

The variations for plant height, shoot dry weight, root dry weight, and root:shoot ratio among these treatments were rather low. Plant heights ranging from 19.2-28.8 cm were observed among treatments (Table 4). Sterilized soil control had the highest plant height $(28.8 \mathrm{~cm})$, whereas B. ubonensis had the lowest plant height $(19.2 \mathrm{~cm})$. Most treatments with bacteria and phosphate were significantly lower than sterilized soil control except for phosphate alone $(25.8 \mathrm{~cm})$, E. hormaechei $(27.2 \mathrm{~cm})$, E. hormaechei + 
Table 5 Effects of phosphate solubilizing bacteria and phosphate solubilizing bacteria plus phosphate on plant height, shoot dry weight and root dry weight of baby corn in pot experiment.

\begin{tabular}{lcccc}
\hline Main effect & $\begin{array}{c}\text { Plant } \\
\text { height } \\
(\mathrm{cm})\end{array}$ & $\begin{array}{c}\text { Shoot } \\
\text { dry weight } \\
(\mathrm{g})\end{array}$ & $\begin{array}{c}\text { Root } \\
\text { dry weight } \\
(\mathrm{g})\end{array}$ & $\begin{array}{c}\text { Root: } \\
\text { shoot } \\
\text { ratio }\end{array}$ \\
\hline Phosphate alone & $25.8^{\mathrm{b}}$ & $4.07^{\mathrm{b}}$ & $1.50^{\mathrm{a}}$ & $0.38^{\mathrm{ab}}$ \\
Bacteria & $23.0^{\mathrm{b}}$ & $4.26^{\mathrm{b}}$ & $1.44^{\mathrm{a}}$ & $0.41^{\mathrm{ab}}$ \\
Bacteria + phosphate & $25.9^{\mathrm{b}}$ & $5.29^{\mathrm{b}}$ & $2.00^{\mathrm{a}}$ & $0.42^{\mathrm{a}}$ \\
Blank control & $28.8^{\mathrm{a}}$ & $7.50^{\mathrm{a}}$ & $2.13^{\mathrm{a}}$ & $0.28^{\mathrm{b}}$ \\
\hline
\end{tabular}

Means in the same column with the same letter(s) are not statistically different at 0.05 probability level by DMRT.

$\mathrm{P}(28.0 \mathrm{~cm})$, B. pyrrocinia $(26.7 \mathrm{~cm})$, and B. izardii $+\mathrm{P}$ $(26.5 \mathrm{~cm})$.

As with plant height, sterilized soil control also had the highest shoot dry weight $(7.50 \mathrm{~g})$, which was not significantly different from most treatments except for P alone (4.07 g), E. cancerogenus (3.35 g), B. pyrrocinia (4.78 g), B. izardii (4.26 g), E. cancerogenus (3.79 g), and B. ubonensis + P (4.34 g).

Sterilized soil control (2.13 g) was not significantly different from most treatments for root dry weight, and the treatment with significantly lower than sterilized soil control was observed in B. izardii $(1.16 \mathrm{~g})$ only. Root:shoot ratios in this study were rather high, ranging from 0.28 in sterilized soil control to 0.61 in B. ubonensis, and only Burkholderia ubonensis was significantly higher than sterilized soil control.

Sterilized soil control was significantly higher than phosphate alone, bacteria and bacteria plus phosphate for plant height and shoot dry weight (Table 5). However, sterilized soil control was not significantly different from other main effects for root dry weight. Sterilized soil control (0.28) was significantly lower than bacteria plus phosphate $(0.42)$ for root:shoot ratio, but the treatment was not statistically different from phosphate alone (0.38) and bacteria (0.41).

Theoretically, application of phosphate and phosphate-solubilizing bacteria should promote shoot growth and root growth of corn, and, therefore, plant height, shoot dry weight and root dry weight of sterilized soil control should be lower than those of phosphate alone, bacteria, or bacteria plus phosphate. In this study, application of phosphate and phosphatesolubilizing bacteria reduced plant height and shoot dry weight of baby corn. The crop did not respond to the application of phosphate or phosphate-solubilizing bacteria for root dry weight. Application of phosphate and phosphate-solubilizing bacteria however did increase root/shoot ratio especially for bacteria + phosphate. The results indicate that application of phosphate and phosphate-solubilizing bacteria promoted root growth but reduced shoot growth.

In a previous study in maize using two efficient strains Serratia marcescens EB 67 and Pseudomonas sp. CDB 35, increase in plant biomass (dry weight) was 99\% with EB 67 and 94\% with CDB 35 under glasshouse conditions ${ }^{32}$. The authors also found that increase in plant biomass at 48 and 96 days after sowing was $66 \%$ and $50 \%$ with EB 67 and $51 \%$ and $18 \%$ with CDB 35 under field conditions. The results of this study supported theoretical expectation for root growth, but not for shoot growth.

The explanation would be the severe stress of the crop especially for water stress superimposed by toxicity of phosphate applied directly to the crop and by solubilizing bacteria hamper plant growth. Stress occurred because the plants were confined to small containers and exposed directly to sun light under open environments. Although water was deliberately controlled, severe stress could not be avoided as indicated by severe reductions in growth and high root:shoot ratio. It is evident that the crop with normal growth will be as high as $2 \mathrm{~m}$, but the crop in this study had plant height lower than $30 \mathrm{~cm}$. Loss in plant high was roughly higher than $80 \%$ and the crop produced no ear. Nutrient availability, uptake, and transport are impaired by drought stress ${ }^{33}$ and, sometimes, high dosages of nutrients cause toxicity to the crop $^{34}$. Root colonization of bacteria, persistence, and performance in the rhizosphere are severely affected by environmental factors, especially under stressful soil conditions.

Inappropriate phosphate forms may cause slow growth in phosphate-treated plants. Rock phosphate and $\mathrm{K}_{3} \mathrm{PO}_{4}$ applied either singly or in combination did not significantly enhance soil availability of $\mathrm{P}$ and $\mathrm{K}$, indicating their unsuitability for direct application ${ }^{35}$. Test of more phosphate forms can answer to this question.

The results, however, are used to the readers who conduct similar research. Larger containers and bigger experimental units are necessary for the experiments. To obtain better results and manageable experiment, numbers of tested bacterial isolates can be reduced. More importantly, deliberate control of water supply to avoid water stress is imperative to obtain optimum growth of the crop and reveal the differences among treatments.

\section{CONCLUSIONS}

The research met our objective in identifying the bacterial isolates with good ability to solubilize phos- 
phate from root zone of many species of bamboo. These isolates belong to Buttiauxella izardii (family Enterobacteriaceae), Burkholderia pyrrocinia, B. ubonensis, E. cancerogenus, and E. hormaechei. B. izardii is the most promising, and others are also worth exploring in further studies to develop bio-fertilizer for baby corn. Unfortunately, the research was not able to confirm their phosphate solubilizing ability in pot experiment with baby corn, and further investigations in details are also required. Although solubilization of $\mathrm{P}$ compounds by microbes is very common under laboratory conditions, results in the field have been highly variable. This variability has hampered the large-scale use of PSMs in agriculture.

Acknowledgements: Kanchanaburi provincial agricultural extension office and Kanchanaburi Rajabhat University are gratefully acknowledged for providing research grant and research facilities. The BIOTEC and National Science and Technology Development Agency (NSTDA) Thailand are also acknowledged for their contribution to bacterial identification.

\section{REFERENCES}

1. Rodríguez H, Fraga R (1999) Phosphate solubilizing bacteria and their role in plant growth promotion. Biotechnol Adv 17, 319-39.

2. Elkoca E, Kantar F, Sahin F (2007) Influence of nitrogen fixing and phosphorus solubilizing bacteria on the nodulation, plant growth, and yield of chickpea. J Plant Nutr 31, 157-71.

3. Han J, Xia D, Li L, Sun L, Yang K, Zhang L (2009) Diversity of culturable bacteria isolated from root domains of moso bamboo (Phyllostachys edulis). Microb Ecol 58, 367-73.

4. Rashid M, Samina K, Najma A, Sadia A, Farooq L (2004) Organic acids production and phosphate solubilization by phosphate solubilizing microorganisms under in vitro conditions. Pakistan J Biol Sci 7, 187-96.

5. Ivanova R, Bojinova D, Nedialkova K (2006) Rock phosphate solubilization by soil bacteria. J Univ Chem Tech Metall 41, 297-302.

6. Kundu BS, Gera R, Sharma N, Bhatia A, Sharma R (2002) Host specificity of phosphate solubilizing bacteria. Indian J Microbiol 42, 19-21.

7. Hafeez FY, Yasmin S, Ariani D, RahmanAM, Zafar Y, Malik KA (2006) Plant growth-promoting bacteria as biofertilizer. Agron Sustain Dev 26, 143-50.

8. Wahyudi AT, Astuti RI, Giyanto (2011) Screening of Pseudomonas sp. isolated from rhizosphere of soybean plant as plant growth promoter and biocontrol agent. Am J Agr Biol Sci 6, 134-41.

9. Jorquera MA, Hernández MT, Rengel Z, Marschner P, Mora M (2008) Isolation of culturable phosphobacteria with both phytate-mineralization and phosphate-solu- bilization activity from the rhizosphere of plants grown in a volcanic soil. Biol Fertil Soils 44, 1025-34.

10. Rodríguez H, Gonzalez T, Selman G (2000) Expression of a mineral phosphate solubilizing gene from Erwinia herbicola in two rhizobacterial strains. J Biotechnol $\mathbf{8 4}$, 155-61.

11. Rodríguez H, Fraga R, Gonzalez T, Bashan Y (2006) Genetics of phosphate solubilization and its potential applications for improving plant growth-promoting bacteria. Plant Soil 287, 15-21.

12. Ruangsanka S (2011) Screening of phosphate solubilizing bacteria from bamboo rhizosphere in Ban$\mathrm{Pu}$-Teuy community forest, Kanchanaburi province. Valaya Alongkorn Rev 2, 51-8.

13. Kawasaki H, Hoshino Y, Hirata A, Yamasato K (1993) Is intracytoplasmic membrane structure a generic criterion? It does not coincide with phylogenetic interrelationships among photosynthetic purple non-sulfur bacteria. Arch Microbiol 160, 358-62.

14. Yamada Y, Katsura K, Kawasaki H, Widyastuti Y, Saono S, Seki T, Uchimura T, Komagata K (2000) Asaia bogorensis gen. nov., sp. nov., an unusual acetic acid bacterium in the $\alpha$-Proteobacteria. Int J Syst Evol Microbiol 50, 823-9.

15. Katsura K, Kawasaki H, Potacharoen W, Saono S, Seki T, Yamada Y, Uchimura T, Komagata K (2001) Asaia siamensis sp. nov., an acetic acid bacterium in the $\alpha$-Proteobacteria. Int J Syst Evol Microbiol 51, 559-63.

16. Brosius J, Dull TJ, Sleeter DD, Noller HF (1981) Gene organization and primary structure of a ribosomal RNA operon from Escherichia coli. J Mol Biol 148, 107-27.

17. Altschul SF, Madden TL, Schaeffer AA, Zhang J, Zhang Z, Miller W, Lipman DJ (1997) Gapped BLAST and PSI-BLAST: a new generation of protein database search programs. Nucleic Acids Res 25, 3389-402.

18. Zhang Z, Schwartz S, Wagner L, Miller W (2000) A greedy algorithm for aligning DNA sequences. $J$ Comput Biol 7, 203-14.

19. Chun J, Lee JH, Jung Y, Kim M, Kim S, Kim BK, Lim YW (2007) EzTaxon: a web-based tool for the identification of prokaryotes based on 16S ribosomal RNA gene sequences. Int J Syst Evol Microbiol 57, 2259-61.

20. Nissen O, Freed RD, Everson EH, Reicosky D, Smail V, Stilwell T (1983) MSTAT-C; A Software Package for the Design, Management, and Analysis of Agronomic Experiments. Crop Soil Sci. Dept., Michigan State Univ., USA.

21. Ruangsanka S (2014) Identification of phosphate-solubilizing fungi from asparagus rhizosphere as antagonist of root and crown rot pathogen, Fusarium oxysporum. Sci Asia 40, 16-20.

22. Malboobi MA, Owlia P, Behbahani M, Sarokhani E, Moradi S, Yakhchali B, Deljou A, Heravi KM (2009) Solubilization of organic and inorganic phosphates by three highly efficient soil bacterial isolates. World $J$ Microbiol Biotechnol 25, 1471-7. 
23. Chen YP, Rekha PD, Arun AB, Shen FT, Lai WA, Young CC (2006) Phosphate solubilizing bacteria from subtropical soil and their tricalcium phosphate solubilizing abilities. Appl Soil Ecol 34, 33-41.

24. Goldstein AH (1995) Recent progress in understanding the molecular genetics and biochemistry of calcium phosphate solubilization by gram negative bacteria. Biol Agr Hort 12, 185-93.

25. Tripti Kumar V, Anshumali (2012) Phosphate solubilizing activity of some bacterial strains isolated from chemical pesticide exposed agriculture soil. Int J Eng Res Dev 3, 1-6.

26. Sharma J, Fulekar MH (2009) Identification of potential strain-Buttiauxella izardii DSM 9397 for remediation of cadmium. Innovat Rom Food Biotechnol 4, $16-23$.

27. Torres AR, Araujo WL, Cursino L, Hungria M, Plotegher F, Mostasso FL, Azevedo JL (2008) Diversity of endophytic enterobacteria associated with different host plants. J Microbiol 46, 373-9.

28. Luvizotto DM, Marcon J, Andreote FD, Dini-Andreote F, Neves AAC, Araújo WL, Pizzirani-Kleiner AA (2010) Genetic diversity and plant-growth related features of Burkholderia spp. from sugarcane roots. World J Microbiol Biotechnol 26, 1829-36.

29. Perin L, Martínez-Aguilar L, Castro-González R, Estrada-de los Santos P, Cabellos-Avelar T, Guedes HV, Reis VM, Caballero-Mellado J (2006) Diazotrophic Burkholderia species associated with field-grown maize and sugarcane. Appl Environ Microbiol 72, 3103-10.

30. Singh MK, Singh DP, Mesapogu S, Babu BK, Bontemps C (2011) Concomitant colonization of nifH positive endophytic Burkholderia sp. in rice (Oryza sativa L.) promotes plant growth. World J Microbiol Biotechnol 27, 2023-31.

31. Estrada P, Mavingui P, Cournoyer B, Fontaine F, Balandreau J, Caballero-Mellado J (2002) A N2-fixing endophytic Burkholderia sp. associated with maize plants cultivated in Mexico. Can J Microbiol 48, 285-94.

32. Hameedaa B, Harinib G, Rupelab OP, Wanib SP, Reddy $\mathrm{G}$ (2008) Growth promotion of maize by phosphate solubilizing bacteria isolated from composts and macrofauna. Microbiol Res 163, 234-42.

33. Raza MAS, Saleem MF, Ashraf MY, Ali A, Asghar HN (2012) Glycinebetaine applied under drought improved the physiological efficiency of wheat (Triticum aestivum L.). Plant Soil Environ 31, 67-71.

34. Brady NC, Weil RR (2008) The Nature and Properties of Soil, 14th edn, Pearson Education, Inc, Upper Saddle River, New Jersey.

35. Han HS, Supanjani Lee KD (2006) Effect of co-inoculation with phosphate and potassium solubilizing bacteria on mineral uptake and growth of pepper and cucumber. Plant Soil Environ 52, 130-6. 